\title{
Investigation of Physical and Motor Characteristics Between University Students Who Participate and Students Who Don't Participate in Sport Activities
}

\author{
Serdar Geri ${ }^{1}$ \\ ${ }^{1}$ School of Physical Education and Sports, Mardin Artuklu University, Mardin, Turkey \\ Correspondence: Serdar Geri, School of Physical Education and Sports, Mardin Artuklu University, 47100, \\ Mardin, Turkey. E-mail: serdargeri@artuklu.edu.tr
}

Received: November 12, 2020

Accepted: December 16, 2020

Online Published: January 29, 2021

doi:10.5539/ies.v14n2p90

URL: https://doi.org/10.5539/ies.v14n2p90

\begin{abstract}
The purpose of this study is to investigate the differences between physical and some motoric characteristics of university students who participate in regular sports training and those who do not. A total of 20 volunteer students, 10 students with an average age of $20.80 \pm 1.69$ and 10 students with an average age of $19.90 \pm 1.45$ without any exercise habits were included in the study. Body circumference measurements, vertical-horizontal jump and strength, flexibility, body mass index, body fat ratio, body circumference measurements, vertical-horizontal jump and claw-back-leg strengths, flexibility, peak and average power values of the participant groups were determined and compared. SPSS 20.0 package program was used to analyze the data. Athlete Students' body density, shoulder circumference, chest circumference, biceps (extension-flexion) circumference, average-peak strength, long-vertical jump, hand claw-back-leg strength were determined to be higher than non-athlete students $(\mathrm{p}<0.05)$. Besides, students doing sports; body weight, body mass index, body fat ratio and waist circumference measurement averages were found to be lower than non-athletes $(p<0.05)$. As a result; it has been observed that the participation of young students in regular sports educations can be effective in preventing the risk of obesity and increases their motoric characteristics.
\end{abstract}

Keywords: exercise, obesity, university students

\section{Introduction}

Participation in regular physical activities is very important for the healthy growth and development of children and young people. In addition to physical development, regular exercise activities provide a wide range of social, behavioral and mental benefits to young people. Having fun and being with friends are among other main reasons for engaging in physical activity and sports for children and adolescents (Edwards \& Tsouros, 2006).

Physical activity and exercise are very important in maintaining and improving health, especially in the prevention and control of chronic diseases such as diabetes, osteoporosis, hypertension, obesity, cancer and depression. Studies have shown that living an active life reduces the risk of hypokinetic diseases such as hypertension, high cholesterol, diabetes and obesity by more than 50\% (Church, 2011; Myers et al., 2004; Warburton et al., 2006).

Although it is known that it has many benefits, it has been emphasized that the level of physical activity has gradually decreased with the advancement of technology in recent years, especially in university students, which reflect the majority of the young adult population (Özer et al., 2020). It is often stated that the origins of obesity and chronic diseases in adults are due to causes such as improper nutrition and sports in childhood and adolescence. Therefore, more than ever before, attention should be paid to children's physical activity, health, and physical fitness (Saygın \& Dükancı, 2009).

Participation in regular exercise during the university and youth years has many gains. In a study conducted in this direction, Özer et al. (2020) reported that the cardiorespiratory endurance values of university students with regular physical activity and exercise habits were more developed than those who did not have regular physical activity and exercise habits. University students stated that they should be informed and directed to sports in line with their health-promoting regular physical activity and exercise habits. 
In the light of this information, body composition and some motor characteristics were examined according to whether university students participated in sports education or not.

\section{Method}

This study was conducted in KTMU University in the 2017-2018 school year. The experimental group consists of student athletes who have attended regular sports (Judo) educations for at least 2 years ( $\mathrm{n}=10$, age: $20.80 \pm 1.69$ years, height: $170.50 \pm 7.76)$ and students who have not received any sports education $(\mathrm{n}=10$, age $19.90 \pm 1.45$ years, height: $169.20 \pm 7.15 \mathrm{~cm}$ ).

\subsection{Bodyweight and Height Measurements}

Height measurements using a fixed tape measure attached to the wall, body weight measurements were measured with digital scales (Heyward \& Wagner, 2004).

\subsection{BMI (Body Mass Index) Values}

It was obtained by weight in kilogram $(\mathrm{kg})$ and dividing that number by its square $\left(\mathrm{m}^{2}\right)$ of the height in metres (m) while calculating the BMI variable (Heyward \& Stolarczyk, 1996)

BMI $\left(\mathrm{kg} / \mathrm{m}^{2}\right)=$ Body weight $(\mathrm{kg}) / \mathrm{Height}(\mathrm{m})^{2}$

\subsection{Body Circumference Measurements}

Non-stretch and non-metallic Gulick anthropometric tape measure (Holtain, UK) with proper methods was used for accurate body circumference measurements (Callaway et al., 1988).

\subsection{Body Fat Measurements}

Body fat percentage was calculated by measuring skinfold thickness with the formula given below (Gledhill \& Jamnik, 2007).

$$
\begin{gathered}
\text { Percentage fat }(\text { Yuhasz })=(i+i i+i i i+i v+v+v i) \times 0.097+3.64 \\
i=\text { chest, } i i=\text { triceps, } i i i=\text { subscapular, } i v=\text { suprailiac, } v=\text { abdomen, } v i=\text { front thigh }
\end{gathered}
$$

\subsection{Body Density Calculation}

The formula which was developed by Jackson \& Pollock was used while calculating the Body Density. In the formula given below, measurements were taken from chest, abdomen and thighs by skinfold caliper method and the data was calculated as mm (Jackson \& Pollock, 1978):

$$
\begin{gathered}
\text { Body Density }=1.10938-[0.0008267 \times(x+y+z)]+\left[0.0000016 \times(x+y+z)^{2}\right]-[0.0002574 \times \text { age }] \\
x=\text { chest, } y=\text { abdomen, } z=\text { thigh }
\end{gathered}
$$

\subsection{Anaerobic Power}

The formula of Johnson and Bahamonde (1996) that is given below was used to calculate the peak and average anaerobic power.

$$
\text { Peak power }(\mathrm{W})=[78.6 \times \text { Vertical jump }(\mathrm{cm})]+[60.3 \times \text { Bodyweight }(\mathrm{kg})]-[15.3 \times \text { Height }(\mathrm{cm})]-1308
$$

Average power $(\mathrm{W})=[43.8 \times$ Vertical jump $(\mathrm{cm})]+[32.7 \times$ Bodyweight $(\mathrm{kg})]-[16.8 \times$ Height $(\mathrm{cm})]+431$

\subsection{Strength Measurements}

Takei brand "Takei-Back \& Lift dynamometer" was used while measuring back and leg strength, and "Takei-Hand Grip dynamometer" was used for claw strength measurement from individuals. Claw Strength measurements were taken from the dominant arm while the individual was standing upright (Heyward, 2002).

\subsection{Statistical Analysis}

Data were analyzed by using IBM SPSS version 20.00 software computer package program. The Shapiro-Wilk test was applied to the data, and it was determined that the data were distributed normally. Parametric tests were preferred in the SPSS program because of the data showed normal distribution. Independent sample t-test was applied to test whether there is a difference in the variables between the students who took judo education and those who did not. A p-value $<0.05$ was considered statistically significant.

\section{Results}

The results were determined from students who participated in regular sports training and those who did not and the differences between the groups are given in the tables below. 
Table 1. Results on the demographic characteristics of student groups $(n=20)$

\begin{tabular}{ccccc}
\hline Variable & $\begin{array}{c}\text { Non-Athlete Students } \\
\bar{x} \pm \text { SD }\end{array}$ & $\begin{array}{c}\text { Athlete Students } \\
\bar{x} \pm \text { SD }\end{array}$ & $\mathrm{t}$ & $\mathrm{p}$ \\
\hline Age (year) & $19.90 \pm 1.45$ & $20.80 \pm 1.69$ & -1.280 & .217 \\
Height $(\mathrm{cm})$ & $169.20 \pm 7.15$ & $170.50 \pm 7.76$ & -0.390 & .701 \\
Weight $(\mathrm{kg})$ & $73.10 \pm 7.23$ & $66.50 \pm 6.22$ & 2.187 & .042 \\
BMI- $\left(\mathrm{kg} / \mathrm{m}^{2}\right)$ & $25.47 \pm 0.68$ & $22.83 \pm 0.64$ & 8.941 & .000 \\
Body fat $(\%)$ & $9.53 \pm 0.48$ & $8.30 \pm 0.57$ & 5.204 & .000 \\
Body density $(\mathrm{g} / \mathrm{ml})$ & $1.0775 \pm 0.003$ & $1.0831 \pm 0.003$ & -4.341 & .000 \\
\hline
\end{tabular}

$\mathrm{p}<0.05$; BMI (body mass index).

As seen in Table 1, there was no statistically significant difference between the age, height and weight characteristics of the student groups $(p>0.05)$. Statistically different results were obtained in favor of the group doing sports in BMI, fat percentage and body density measurement results $(\mathrm{p}<0.05)$.

Table 2. Body circumference and flexibility measurement results according to whether students participate in Regular Sports or not $(\mathrm{n}=20)$

\begin{tabular}{ccccc}
\hline Variable & $\begin{array}{c}\text { Non-Athlete Students } \\
\bar{x} \pm \text { SD }\end{array}$ & $\begin{array}{c}\text { Athlete Students } \\
\bar{x} \pm \text { SD }\end{array}$ & $\mathrm{t}$ & $\mathrm{p}$ \\
\hline Neck c. $(\mathrm{cm})$ & $36.90 \pm 0.87$ & $37.50 \pm 0.85$ & -1.555 & .137 \\
Shoulder c. $(\mathrm{cm})$ & $108.50 \pm 6.80$ & $114.70 \pm 6.20$ & -2.161 & .044 \\
Chest c. $(\mathrm{cm})$ & $89.70 \pm 5.40$ & $96.20 \pm 6.20$ & -2.501 & .022 \\
Biceps c. ext $(\mathrm{cm})$ & $27.20 \pm 2.20$ & $32.00 \pm 2.50$ & -4.609 & .000 \\
Biceps c. flx $(\mathrm{cm})$ & $29.60 \pm 1.83$ & $34.10 \pm 2.28$ & -4.856 & .000 \\
Waist c. $(\mathrm{cm})$ & $77.10 \pm 4.41$ & $72.70 \pm 4.37$ & 2.241 & .038 \\
Hip c. $(\mathrm{cm})$ & $89.80 \pm 3.91$ & $90.10 \pm 4.04$ & -0.169 & .868 \\
Femur c. $(\mathrm{cm})$ & $34.20 \pm 2.04$ & $35.30 \pm 2.54$ & -1.067 & .300 \\
\hline
\end{tabular}

$\mathrm{p}<0.05$; c. (Circumference); ext (extension); flx (flexion).

The average measurement of the shoulder, chest, and biceps (flx-ext) circumferences of the student group doing sports was found to be significantly higher than the students who do not do sports $(\mathrm{p}<0.05)$. Also waist results, it was found that the value obtained from students who do sports is significantly lower than the group who do not do sports $(p<0.05)$. It was determined that the other compared body circumference characteristics (neck, hip and femur) were at a similar level.

Table 3. Results regarding strength and strength according to whether the students participate in regular sports or $\operatorname{not}(\mathrm{n}=20)$

\begin{tabular}{ccccc}
\hline Variable & $\begin{array}{c}\text { Non-Athlete Student } \\
\bar{x} \pm \text { SD }\end{array}$ & $\begin{array}{c}\text { Athlete Students } \\
\bar{x} \pm \text { SD }\end{array}$ & $\mathrm{t}$ & $\mathrm{p}$ \\
\hline Average power (watt) & $1082.57 \pm 194.19$ & $1383.65 \pm 254.34$ & -2.974 & .008 \\
peak power (watt) & $3798.98 \pm 58.20$ & $4347.49 \pm 501.98$ & -2.821 & .011 \\
Long jump (cm) & $208.60 \pm 22.65$ & $230.00 \pm 17.16$ & -2.382 & .028 \\
Vertical jump (cm) & $25.20 \pm 5.80$ & $37.50 \pm 6.13$ & -4.612 & .000 \\
Hand claw strength-D. (kg) & $42.80 \pm 4.34$ & $46.60 \pm 3.02$ & -2.271 & .036 \\
Back strength (kg) & $89.50 \pm 11.16$ & $102.70 \pm 14.84$ & -2.247 & .037 \\
Leg strength (kg) & $108.10 \pm 19.96$ & $125.50 \pm 13.43$ & -2.287 & .034 \\
\hline
\end{tabular}

$\mathrm{p}<0.05 ; \mathrm{D}$ (Dominant).

In all parameters related to strength and strength seen in Table 3, statistically significant results were found in favor of the student group doing regular sports $(\mathrm{p}<0.05)$. 


\section{Discussion}

In recent years, childhood and adolescent obesity has become an important health problem due to the decrease in sports training and physical activity. The sedentary lifestyle in this period may invite cardiovascular diseases and obesity in the future (Baltacı \& Düzgün, 2008).

In the study, average values of body fat ratios determined from students who are included in sports training were found to be low compared to students who do not do sports. Body density averages determined from athlete students were also found to be statistically significantly lower $(\mathrm{p}<0.05)$ compared to the other group (Table 1). Bilim et al. (2016) in their study reported that students' body fat percentage and body mass index values were lower than students who did not participate in school sports. It is known that regular sports activities cause a decrease in body fat percentages. Accordingly, studies indicating that regular physical activities decrease the body amount of body fat important in terms of supporting our findings (Jurimae \& Jurimae, 2001; Gümüşdağ \& Kartal, 2017; Tekin et al., 2015). World health organization (2020) while classifying BMI values; 18.5-24.9 are considered normal; 25.9-29.9 are overweight, 30 and over are considered obese (WHO, 2020). As can be seen, BMI values determined by students who do not do sports in our study are defined as overweight. In the study, the averages of $22.83 \pm 0.64\left(\mathrm{~kg} / \mathrm{m}^{2}\right)$ determined from the students who do sports regularly are important in terms of understanding the positive effects of regular sports training on young people.

According to the environmental measurements determined in our study, the average of shoulder, chest and biceps (flx-ext) circumference of the athlete students were found to be significantly higher than the students who do not do sports $(\mathrm{p}<0.05)$. In the waist results, it was found that the value obtained from the students who do sports is significantly lower than the non-sports group $(\mathrm{p}<0.05)$. It was determined that other measured environmental characteristics were at a similar level ( $\mathrm{p}>0.05$ ), (Table 2).

The high average of chest and shoulder circumference detected from students who do sports is thought to be due to the positive effects of regular sports training on muscles. In a study, it was reported that the diameter of the muscle increased when stimulated at a high strain (Sevim, 1997). Also, resistance training has been reported to increase lean body mass and decrease body fat percentage (Fenicchia et al., 2004; Shaibi et al., 2007). Studies that indicate that there may be a decrease in body fat between $1-9 \%$ as a result of training (Fleck \& Kraemer, 1997) can be considered as clear evidence that the waist regions of athletes are lower than the non-sports group.

In the study, according to the results obtained from the parameters related to strength and strength; in all parameters related to strength and strength, statistically significant results were found in favor of the student group doing sports regularly $(\mathrm{p}<0.05)$ (Table 3 ). In a study on the subject, the values of male students engaged in sports and sedentary were examined. Those who do sports have been reported to show more successful results in performance-related physical fitness tests (muscular strength, muscular endurance, speed and cardiovascular endurance (Bilim et al., 2016).

In the study, the standing and long jump scores of the student group doing sports were found to be significantly higher than the group who did not do sports $(\mathrm{p}<0.05)$. Kizilet et al. (2010) they concluded that plyometric training applied for 8 weeks significantly increased the results of the long jump by stopping athletes, and it was reported that the long jump scores increased by $9.2 \%$ as a result of special training. In another study Aydos and Kürkçü (1997), found a significant difference in the long jump and vertical jump averages of students who do sports and those who do not, in favor of the group doing sports. These reviewed literatures are similar to our long jump and vertical jump findings.

In the study, the regional strength average of the students who do sports regularly was found to be significantly higher than the students who do not do sports (Table 3). In reported research, the claw, back, and leg strength of children who participated in sports and those who did not were examined. In research on the subject, they found that the averages of the group participating in sports training were significantly higher than the group who did not (Kalayc1 et al., 2009). Accordingly, those results are positive reflections of regular exercises on strength development. In the study, the average of anaerobic (average-peak) strength determined from the student group doing sports reflected significantly higher values compared to the students who did not do sports $(p<0.05)$. It has been stated that the increases in strength parameters such as leg strength are directly related to the increase in anaerobic power. The high levels of anaerobic power detected were thought to be related to the increase in the leg and back strength (Çimen \& Günay, 1996) (Table 3).

According to the results of the research findings, it has been observed that the participation of young students in regular sports educations can be effective in preventing the risk of obesity and increases their motoric characteristics. 


\section{References}

Aydos, L., \& Kürkçü, R. (1997). 13-18 yaş grubu spor yapan ve yapmayan orta öğrenim gençliğinin fiziksel ve fizyolojik özelliklerinin karşılaştırılması. Gazi Beden Eğitimi ve Spor Bilimleri Dergisi, 2(2), 31-38. Retrieved from https://dergipark.org.tr/en/download/article-file/284253

Baltacı, G., \& Düzgün, İ. (2008). Adolesan ve egzersiz. Sağlık Bakanlı̆̆ı Yayınları, Birinci Basım, Yayın No, 730. Retrieved from https://sbu.saglik.gov.tr/Ekutuphane/kitaplar/t40.pdf

Bilim, A. S., Çetinkaya, C., \& Dayı, A. (2016). Investigation of physical fitness of 12-17 years old students who engage and do not engage in sports. Journal of Sports and Performance Researches, 7(2), 53-60. https://doi.org/10.17155/spd.74209

Callaway, C. W., Chumlea, W. C., Bouchard, C., Himes, J. H., Lohman, T. G., Martin, A. D., ... Seefeldt, V. D. (1988). Circumference in anthropometric standardization reference manual. In T. G. Lohman, A. F. Roche, \& R. Martorell (Eds.), Champaign, Human Kinetics Books (pp. 39-54).

Church, T. (2011). Exercise in obesity, metabolic syndrome, and diabetes. Progress in Cardiovascular Diseases, 53(6), 412-418. https://doi.org/10.1016/j.pcad.2011.03.013

Çimen, O., \& Günay, M. (1996). Dairesel çabuk kuvvet antrenmanlarının 16-18 yaş grubu genç erkek masa tenisçilerin bazı motorik özelliklerine etkisi. Spor Bilimleri Dergisi, 7(3), 3-11. Retrieved from http://www.sbd.hacettepe.edu.tr/fulltext/1996_3_1.pdf

Edwards, P., \& Tsouros, A. (2006). Kentsel Çevrede Fiziksel Aktivite ve Aktif Yaşamın Desteklenmesi. Bilimsel Kanitlar. Dünya Sağlık Örgütü. http://www.skb.gov.tr/wp-content/uploads/2010/07/Kentsel_cevrede_fiziksel_a.pdf

Fenicchia, L. M., Kanaley, J. A., Azevedo Jr, J. L., Miller, C. S., Weinstock, R. S., Carhart, R. L., \& Ploutz-Snyder, L. L. (2004). Influence of resistance exercise training on glucose control in women with type 2 diabetes. Metabolism, 53(3), 284-289. https://doi.org/10.1016/j.metabol.2003.10.007

Fleck, S., \& Kraemer, W. (1997). Designing resistance training programs (2nd ed.). Champaign, III: Human Kinetics Books.

Gledhill, N., \& Jamnik, V. (2007). Detailed fitness and medical assessment protocols for NHL entry draft players. Toronto: York University.

Gümüşdağ, H., \& Kartal, A., (2017). Investigation of effectiveness of body composition in 8 weekly aerobic exercise applied to obese ladies. The Journal of International Anatolia Sport Science, 4, 227-236. https://doi.org/10.22326/ijass.24

Heyward, V. H. (2002). Advanced fitness assessment and exercise prescription (4th ed.). Champaign, IL: Human Kinetics.

Heyward, V. H., \& Stolarczyk, L. M. (1996). Applied body composition assessment. Champaign, IL: Human Kinetics.

Heyward, V. H., \& Wagner, D. R. (2004). Applied body composition assessment (2nd ed.). Champaign: Human Kinetics.

Jackson, A. S., \& Pollock, M. L. (1978). Generalized equations for predicting body density of men. British Journal of Nutrition, 40(3), 497-504. https://doi.org/10.1079/BJN19780152

Johnson, D. L., \& Bahamonde, R. (1996). Power output estimate in university athletes. Journal of Strength and Conditioning Research, 10, 161-166. https://doi.org/10.1519/00124278-199608000-00006

Jurimae, T., \& Jurimae, J. (2001). Growth, physical activity, and motor development in prepubertal children. Boca Raton, FL.: CRC Press. https://doi.org/10.1201/b14219

Kalaycı, M. C., Gönültaş, B., Akçınar, F., Özaltaş, H. N., \& Akyol, B. (2019). Posture, flexibility, body fat ratio, hand grip, leg and back strength values of girls aged 10-12 according to their participation in volleyball training. 3rd International Health Sciences Conference (IHSC 2019) Proceeding Book (pp. 669-676).

Kızılet, A., Atılan, O., \& Erdemir, İ. (2010). 12-14 yaş grubu basketbol oyuncularının çabukluk ve sıçrama yetilerine farklı kuvvet antrenmanlarının etkisi. Atabesbd, 12(2), 44-57. Retrieved from https://dergipark.org.tr/tr/pub/ataunibesyo/issue/28837/308544

Myers, J., Kaykha, A., George, S., Abella, J., Zaheer, N., Lear, S., ... Froelicher, V. (2004). Fitness versus physical activity patterns in predicting mortality in men. The American Journal of Medicine, 117(12), 
912-918. https://doi.org/10.1016/j.amjmed.2004.06.047

Özer Kaya, D., Naz Gürşan, İ., Günay Uçurum, S., Emük, Y., Büker, N., \& Ongan, D. (2020). Düzenli fiziksel aktivite ve egzersiz alışkanlığı olan ve olmayan üniversite öğrencilerinin fiziksel uygunluklarının karşılaştırılması: ön çalışma. İzmir Katip Çelebi Üniversitesi Sağlık Bilimleri Fakültesi Dergisi, 5(3), 249-254. Retrieved from https://dergipark.org.tr/en/pub/ikcusbfd/issue/57021/753415

Saygın, Ö., \& Dükancı, Y. (2009). Kız çocuklarda sağlık ilişkili fiziksel uygunluk ve fiziksel aktivite yoğunluğu ilişkisinin araştırılması. Uluslararası insan bilimleri dergisi, 6(1), 320-329. Retrieved from https://www.j-humansciences.com/ojs/index.php/IJHS/article/view/660/348

Sevim, Y. (1997). Antrenman Bilgisi. Tutibay Ltd.Şti Ankara.

Shaibi, G. Q., Cruz, M. L., Ball, G. D., Weigensberg, M. J., Salem, G. J., Crespo, N. C., \& Goran, M. I. (2006). Effects of resistance training on insulin sensitivity in overweight Latino adolescent males. Medicine and science in sports and exercise, 38(7), 1208-1215. https://doi.org/10.1249/01.mss.0000227304.88406.0f

Tekin, A., Tekin, G., Çalışır, M., \& Bayrakdaroğlu, S. (2015). Düzenli aerobik egzersiz programının üniversiteli obez kız öğrencilerin fiziksel, motorik ve psiko-sosyal parametrelerine etkisi. Spor ve Performans Araştırmaları Dergisi, 6(1), 19-29. https://doi.org/10.17155/spd.42220

Warburton, D. E., Nicol, C. W., \& Bredin, S. S. (2006). Health benefits of physical activity: the evidence. Cmaj, 174(6), 801-809. https://doi.org/10.1503/cmaj.051351

World Health Organization. (2020). Body mass index-BMI. Retrieved from https://www.euro.who.int/en/healthtopics/disease-prevention/\%20nutrition/a-healthy-lifestyle/body-mass-index-bmi

\section{Copyrights}

Copyright for this article is retained by the author(s), with first publication rights granted to the journal.

This is an open-access article distributed under the terms and conditions of the Creative Commons Attribution license (http://creativecommons.org/licenses/by/4.0/). 